\title{
The myth of Prometheus depicted by Jacob Jordaens in 1640
}

\author{
Thomas M. van Gulik \\ Department of Surgery, Amsterdam University Medical Centers, University of Amsterdam, Amsterdam, The Netherlands \\ Correspondence to: Thomas M. van Gulik, MD, PhD. Department of Surgery, Amsterdam University Medical Centers, University of Amsterdam, \\ Amsterdam, The Netherlands. Email: t.m.vangulik@amsterdamumc.nl.
}

Submitted Oct 29, 2020. Accepted for publication Nov 10, 2020.

doi: $10.21037 / \mathrm{hbsn}-2020-7$

View this article at: http://dx.doi.org/10.21037/hbsn-2020-7

Jacob Jordaens (1593-1678) was a Flemish artist who lived and worked in Antwerp, Belgium.

His painting shows a scene of the myth of Prometheus, the pre-Olympian god who was punished by Zeus, the king of the gods, because he had stolen the fire of the Olympian gods to give to mankind. Because of this Olympic fire, humans were endowed with the ability to think and feel, with which they could cultivate science and arts. He was chained to a rock of the Caucasus mountains and every day, an eagle came and ate part of his liver. Each night, his liver would regrow enabling him to endure his punishment for eternity (1). The myth of Prometheus has inspired artists and scientists alike and in medicine, has become the symbol of the regenerative capacity of the liver. Did the ancient Greeks, 2,500 years ago, know about the ability of the liver to regenerate and were they aware that this capacity was inexhaustible? This is not likely since they had no knowledge of the anatomy of the liver, let alone its functions. In their perception, it was characteristic of all gods that their organs and limbs would regrow after having sustained a loss. Like the mythological snake-monster with the nine heads, the Hydra; if you would chop off one head, two heads would regrow at the same place in return!

\section{Acknowledgments}

The painting by Jacob Jordaens was used courtesy of the WalraffRichartz Museum \& Foundation Corboud, Cologne, Germany. Photo: Rheinisches Bildarchiv Cologne, rba_c007696.

Funding: None.

\section{Footnote}

Provenance and Peer Review: This article was commissioned by the editorial office, Hepatobiliary Surgery and Nutrition. The article did not undergo external peer review.

Conflicts of Interest: The author has completed the ICMJE uniform disclosure form (available at https://hbsn. amegroups.com/article/view/10.21037/hbsn-2020-4/coif). TM van Gulik serves as an unpaid editorial board member

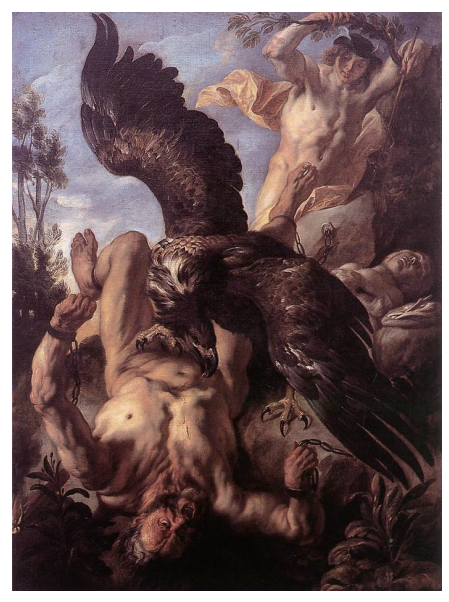

of Hepatobiliary Surgery and Nutrition. The author has no other conflicts of interest to declare.

Ethical Statement: The authors is accountable for all aspects of the work in ensuring that questions related to the accuracy or integrity of any part of the work are appropriately investigated and resolved.

Open Access Statement: This is an Open Access article distributed in accordance with the Creative Commons Attribution-NonCommercial-NoDerivs 4.0 International License (CC BY-NC-ND 4.0), which permits the noncommercial replication and distribution of the article with the strict proviso that no changes or edits are made and the original work is properly cited (including links to both the formal publication through the relevant DOI and the license). See: https://creativecommons.org/licenses/by-nc-nd/4.0/.

\section{References}

1. Tiniakos DG, Kandilis A, Geller SA. Tityus: a forgotten myth of liver regeneration. J Hepatol 2010;53:357-61.

Cite this article as: van Gulik TM. The myth of Prometheus depicted by Jacob Jordaens in 1640. HepatoBiliary Surg Nutr 2020;9(6):693. doi: 10.21037/hbsn-2020-7 